\title{
OS PRINCÍPIOS DA PROPORCIONALIDADE E DA RAZOABILIDADE E O DIREITO TRIBUTÁRIO
}

\author{
ROGÉRIO LEITE LOBO*
}

\begin{abstract}
1. Introdução; 2. Origens e Conceituação dos Princípios da Proporcionalidade e da Razoabilidade; 2.1. A Importância das Origens Históricas; 2.2. As Distintas Fontes dos Principios; 2.3. A Conceituação dos Princípios; 2.4. O Uso Conjugado dos Principios na "Hermenêutica Pós-Positivista"; 3. Os Princípios da Proporcionalidade è da Razoabilidade e sua Aplicação no Direito Tributário; 3.1. A Cláusula do Devido Processo Legal Substantivo como Matriz da Aplicação Concreta dos Principios; 3.2. Exemplos de Aplicação Concreta dos Princípios no Direito Tributário; 3.3. O Âmbito Maior de Aplicação dos Princípios da Proporcionalidade e da Razoabilidade nos Litígios Tributários; 4. Conclusões.
\end{abstract}

\section{Introdução}

O presente trabalho tem por objetivo breve investigação relacionada ao emprego dos princípios da proporcionalidade e da razoabilidade no âmbito do Direito Tributário. Para tanto serão inicialmente resgatadas as origens históricas de cada um dos cânones, o que propiciará venham à tona algumas distinções conceituais que se afigurarão importantes na aplicação prática de um e de outro.

Verificar-se-á, a seguir, em qual medida os princípios da proporcionalidade e da razoabilidade servem de instrumental na chamada "hermenêutica pós-positivista", que privilegia a ponderação dos princípios e valores plasmados na Constituição quando da busca por solucionar os litígios que envolvam um circunstancial confronto entre estes.

* Procurador do Município do Rio de Janeiro. Advogado. Mestre em Direito Tributário pela UCAM-RJ.

R. Dir. Adm.,

Rio de Janeiro, 239: 241-253,

Jan./Mar. 2005 
Então, chegando à seara tributária em si, serão coligidos exemplos, trazidos pela doutrina e pela jusrisprudência da Corte Maior, de hipóteses específicas em que a aplicação dos cânones da proporcionalidade e da razoabilidade possam servir ou tenham servido ao deslinde de casos concretos - fazendo-se expressa menção aos autores e/ou aos julgados pertinentes.

Finalmente, apresentadas algumas hipóteses concretas como acima proposto, abrir-se-á o trabalho para a perscrutação de um espaço mais amplo de atuação dos princípios da proporcionalidade e da razoabilidade no campo do Direito Tributário, no intento de localizar com maior apuro os lindes desse espaço de atuação, que grassa especialmente no equacionamento das soluções dos litígios instaurados entre os contribuintes e as Fazendas Públicas.

\section{Origens e Conceituação dos Princípios da Proporcionalidade e da Razoabilidade}

2.1. Embora alguns autores não se preocupem em verificar as origens históricas dos princípios da proporcionalidade e da razoabilidade quando a eles se referem. ver-se-á que mínimas informações sobre a gênese desses cânones - especialmente as suas modernas matrizes - se afigurarão importantes instrumentos tanto na conceituação de cada qual, quanto, depois, no esforço para anotar distinções que melhor delimitem aquelas linhas conceituais.

Mais ainda, sabendo-se que no exercício da hermenêutica pós-positivista ${ }^{\prime}$ os princípios em foco exsurgem como poderosos veículos para a concretização dos direitos consagrados na Constituição, os elementos distintivos servirão para realçar as nuances na aplicação prática de um e de outro, quando se fará necessário certo fechamento da textura aberta que a ambos caracteriza.

2.2. De uma maneira geral a doutrina tende a localizar na cláusula do devido processo legal uma origem comum para ambos os princípios, especialmente a partir das Emendas V e XIV da Constituição Norte-Americana, e da evolução do alcance meramente procedimental daquela cláusula para uma compreensão substantiva ou material do instituto, "indo além da mera definição de normas processuais, buscando a garantia dos valores fundamentais do cidadão".?

I Para Luis Roberto Barroso, "A perspectiva pós-positivista e principiológica do Direito influenciou decisivamente a formaçāo de uma moderna hermenêutica constitucional. Assim, ao lado dos princípios materiais envolvidos, desenvolveu-se um catálogo de princípios instrumentais e específicos de interpretação constitucional". ["Fundamentos Teóricos e Filosóficos do Novo Direito Constitucional Brasileiro" in: A Nova Interpretação Constitucional - Ponderação, Direitos Fundamentais e Relações Privadas (org.: Luis Roberto Barroso), Ed. Renovar, Rio de Janeiro, 2003. p. 34].

2 Denise Lucena Cavalcante, "A Razoabilidade e a Proporcionalidade na Interpretação Judicial das Normas Tributárias", in: Temas de Interpretação do Direito Tributário (org.: Ricardo Lobo Torres). Ed. Renovar, Rio de Janeiro, 2003, p. 42. 
Conquanto se reconheça cabível tal entendimento, uma análise mais percuciente do processo histórico revela que também outras e diferentes vertentes teriam contribuído para a consolidação dos cânones da proporcionalidade e da razoabilidade em suas modernas acepções.

Após alocar as origens mais remotas da proporcionalidade nas noções de "justa medida" ou "justa proporção" existentes na "filosofia clássica da Antigüidade", DANIEL SARMENTO busca nas decisões do Conséil D'État francês atinentes ao desvio de poder da autoridade administrativa seus substratos mais recentes, chegando às decisões da Corte Constitucional alemã no pós II Guerra como o marco zero da constitucionalização do princípio:

"A preocupação da Corte Constitucional germânica com a proteção dos direitos fundamentais diante dos possíveis abusos do legislador, levou-a a transplantar, para o direito constitucional daquele país, o princípio da proporcionalidade - às vezes também denominado como princípio da proibição do excesso - , que passou a ser utilizado com frequiência como parâmetro para o controle de constitucionalidade das leis." ${ }^{3}$

Também HELENILSON CUNHA PONTES ${ }^{4}$ e RICARDO AZIZ CRETTON frisam a matriz jurisprudencial germânica da moderna acepção do cânone da proporcionalidade ou do "princípio da proibição do excesso", como passou a ser invocado pelo Tribunal Constitucional, "alçando-o à categoria de princípio constitucional implicito". 5

Já o princípio da razoabilidade, este sim, teria suas origens fincadas no direito anglo-saxão e na cláusula do due process of law, desde a Magna Carta de 1215, passando pela alteração da frase "legem terrae" para a expressão "due process of law" em 1354, chegando enfim à Constituição Norte-Americana com as Emendas $\mathrm{V}$ e XIV, esta aprovada em $1866 .^{6}$

Do magistério de DANIEL SARMENTO depreende-se que a evolução do devido processo legal para uma concepção substantiva deu-se em sede jurisprudencial na Suprema Corte Norte-Americana, girando do eixo das liberdades econômicas para o dos direitos fundamentais a partir da década de 1930, e, mais concretamente, durante os litígios relativos aos "direitos e liberdades civis" ocorridos nas décadas de 60 e 70, transformando-se, desde então, " num poderoso instrumento para a defesa

3 A Ponderação de Interesses na Constituição Federal, Ed. Lumen Juris, Rio de Janeiro, 2002, p. 80 .

4 "O Princípio da Proporcionalidade e o Direito Tributário", Ed. Dialética, São Paulo, 2000. pp. $46 / 47$.

5 Os Princípios da Proporcionalidade e da Razoabilidade e sua Aplicação no Direito Tributário, Ed. Lumen Juris, Rio de Janeiro, 2001, p. 58.

6 Conf. Paulo Roberto Lyrio Pimenta, "A Razoabilidade das Leis Tributárias", in: Tributos e Direitos Fundamentais (org.: Octavio Campos Fischer), Ed. Dialética, São Paulo, 2004, pp. 296/297. 
dos direitos constitucionais do cidadão norte-americano diante dos caprichos do legislador":

"Assim, muito embora a maleabilidade inerente a cláusula do due process of law torne difícil sua conceituação precisa, é possível afirmar que a aplicação deste princípio tem permitido ao Poder Judiciário, no direito norte-americano, o exercício do controle sobre a razoabilidade e a racionalidade das leis, sobretudo daquelas que repercutem sobre direitos fundamentais"?

Na mesma trilha, RICARDO AZIZ CRETTON sublinha esse trajeto de migração do cânone da razoabilidade nas decisões da Suprema Corte Norte-Americana, desde as liberdades econômicas para os direitos fundamentais, sob os auspícios da cláusula do substantive due process of law. ${ }^{8}$

2.3. Indicadas ainda sucintamente as distintas origens históricas dos princípios da proporcionalidade e da razoabilidade, restará menos penoso sublinhar os traços dessemelhantes na tipologia de um e de outro, e bem assim as diferenças na prática de suas utilizações - embora, ao final, conceda-se que ambos se complementam como instrumentais da hermenêutica constitucional que privilegia os princípios e a ponderação de valores na solução dos litígios concretos.

Não obstante os alcunhe de "postulados normativos" - evitando deliberadamente nomeá-los de "princípios" - HUMBERTO ÁVILA estabelece interessante e pertinente traço discriminatório entre a proporcionalidade e a razoabilidade: enquanto a aplicação daquele postulado pressuporia uma relação de causalidade meiofim (com o exame dos elementos em que a proporcionalidade se desdobra: adequação, necessidade e proporcionalidade em sentido estrito) no ato interpretado, esta última - a razoabilidade - operaria apenas no balizamento entre o critério e a medida adotados no ato interpretado, na busca do dever de eqüidade, de congruência ou de equivalência intrínseco ao ato: e conclui:

"Com efeito, o postulado da proporcionalidade pressupõe a relação de causalidade entre o efeito de uma ação (meio) e a promoção de um estado de coisas (fim). Adotando-se o meio, promove-se o fim: o meio leva ao fim. Já na utilização da razoabilidade como exigência de congruência entre o critério de diferenciação escolhido e a medida adotada há uma relação entre uma qualidade e uma medida adotada: uma qualidade não leva à medida, mas é critério intrínseco a ela." 9

Outra diferenciação que a doutrina propõe haver entre os princípios se vincula à idéia de que enquanto " a razoabilidade deve ser entendida como uma medida

7 Ob. cit., p. 86.

8 Ob. cit., pp. $45 / 56$.

9 Teoria dos Princípios - da definição à aplicação dos princípios jurídicos, Ed. Malheiros, São Paulo, 2003, pp. 102/103. 
negativa (no sentido de deixar de), a proporcionalidade é uma medida positiva" . ${ }^{0}$ Tal distinção é melhor explorada e explicada por RICARDO AZIZ CRETTON, que, firme no escólio de Willis Santiago Guerra Filho, aduz:

"São diversos os dois princípios na origem e em sua destinação; enquanto o da razoabilidade teria uma função negativa (não ultrapassar os limites do juridicamente aceitável), o da proporcionalidade seria assinalado por uma função positiva (demarcar aqueles limites, indicando como nos mantermos dentro deles)." 11

Já HELENÍLSON CUNHA PONTES sumariza em quatro itens as diferenças que vislumbra haver entre os princípios em questão: 1) é maior na proporcionalidade que na razoabilidade a exigência de motivação racional da decisão que os aplica; 2) quanto ao conteúdo, a proporcionalidade exige um juízo acerca da relação meiofim, no que prescinde a razoabilidade; 3) quanto à natureza, a razoabilidade consubstanciaria um princípio geral de interpretação, enquanto a proporcionalidade consolidaria verdadeiro princípio jurídico material, decorrente do Estado Democrático de Direito; e 4) quanto às funções eficaciais, a razoabilidade teria função de bloqueio, e a proporcionalidade, além desta função, desempenharia também uma função de resguardo. ${ }^{12}$

Percebe-se que o professor paulista acima aludido promove verdadeiro resumo das distinções referidas pelos demais autores antes mencionados, sistematizando-as através dos critérios que julga pertinentes para tal empreitada. Mais ainda, ao contrário do que entende LUIS ROBERTO BARROSO - que simplesmente não distingue entre os dois cânones aqui versados ${ }^{13}$ - parece sim, se não imprescindível, ao menos bastante útil diferençá-los desde suas matrizes históricas, até as funções nem sempre coincidentes que exercem quando aplicados para a solução de litígios concretos ou mesmo para contrastar os atos de autoridade baixados pelo Poder Público.

Do que se pode apreender das manifestações acima coligidas, ter-se-ia, enfim, o cânone da razoabilidade com uma textura mais subjetiva, operando no nível hermenêutico em si, enquanto que a proporcionalidade (a proibição do excesso) adquiriria natureza material ou substancial, com aplicação objetiva no balanceamento de valores e princípios, normalmente à vista de atos de autoridade. ${ }^{14}$

10 Denise Lucena Cavalcanti, ob.cit., pp. $43 / 44$.

11 Ob. cit., p. 73.

12 Ob. cit., pp. $86 / 90$.

13 Dispõe Luis Roberto Barroso: "O primeiro (princípio da razoabilidade) percorreu longa trajetória no direito anglo-saxão - notadamente nos Estados Unidos - e chegou ao debate nacional amadurecido pela experiência alemä, que o vestiu com a argumentação romano-germânica e batizou-o de princípio da proporcionalidade". - deixando claro que, ao seu sentir, a proporcionalidade nada mais é que uma outra designação para a razoabilidade, ambos irmanados em essência. (Ob. cit., p. 36).

14 Assim também entende Ricardo Aziz Cretton. ob. cit., p. 75. 
2.4. Entretanto, firmadas as linhas básicas que servem para os distinguir, mister conceder, como antes adiantado, que tanto o princípio da razoabilidade quanto o da proporcionalidade se irmanam na qualificação de princípios de interpretação constitucional sob o espaço da hermenêutica pós-positivista, em que a técnica unidirecional da subsunção - tida como insuficiente para a solução concreta dos chamados "hard cases" (aqueles cujo deslinde implicaria a aplicação de normas ou princípios contraditórios ou opostos) - dá lugar a um processo mais complexo de ponderação de princípios ou valores, na busca da decisão (da interpretação) mais justa. ${ }^{15}$

Por isso que mesmo os autores que deixam de se referir à proporcionalidade ou à razoabilidade como "princípios", não deixam, entretanto, de os tratar com a relevância que merecem e adquirem quando o hermeneuta do Direito é chamado a intervir nos casos concretos que demandam a ponderação de valores (ou de outros princípios constitucionais de natureza material) para o atingimento das soluções que se afigurem as mais justas - sob os critérios da racionalidade, da adequação, da necessidade ou da proporcionalidade no sentido estrito. ${ }^{16}$

Em síntese, o reconhecimento da superação do "silogismo de subsunção" que pautou o positivismo na metodologia da aplicação do Direito até as últimas décadas do século passado, faz surgir a técnica da ponderação de valores e princípios como a mais adequada à solução das controvérsias de difícil deslinde, trazendo à tona, daí, os princípios da proporcionalidade e da razoabilidade como importantes "postulados normativos da interpretação / aplicação do direito" ${ }^{17}$ dessa nova metodologia:

"Em torno dessas posturas que resgatam os valores, desenvolvem-se contemporaneamente diversas teorias filosóficas e metodológicas, recepcionadas hermeneuticamente pelos Tribunais Constitucionais por intermédio da aplicação dos testes de razoabilidade e de proporcionalidade, mormente na ponderação e no balanceamento de princípios indexados a direitos fundamentais". 18

3. Os Princípios da Proporcionalidade e da Razoabilidade e sua Aplicação no Direito Tributário:

3.1. Sem embargo das noções acima arroladas, no Brasil, conquanto juristas do naipe de JUAREZ FREITAS pugnem por sua autonomia em relação a quaisquer

15 Conf. Luís Roberto Barroso e Ana Paula de Barcellos, O Começo da História. A Nova Interpretação Constitucional e o Papel dos Princípios no Direito Brasileiro, in: A Nova Interpretação Constitucional, cit., pp. 327 e segs.

16 Humberto Ávila, ob. cit., pp. 120/121, especialmente os itens 4.8 a 4.14.

17 Também Eros Roberto Grau, mesmo negando-se a os chamar de "princípios", lavra a seguinte assertiva. situando a proporcionalidade e a razoabilidade no nível dos "postulados de interpretação constitucionais": "Proporcionalidade e razoabilidade são, destarte, postulados normativos de interpretaçãolaplicação do direito - um novo nome dado aos velhos e desprezados cânones da interpretação - e não princípios". (Ensaio e Discurso sobre a Intepretação/Aplicação do Direito, Ed. Malheiros, São Paulo, 2002, p. 170).

18 Ricardo Aziz Cretton, ob. cit., p. 150. 
outros cânones ${ }^{19}$, os princípios da proporcionalidade e da razoabilidade têm sua aplicação concreta, via de regra, e especialmente nos julgados do Supremo Tribunal Federal, vinculada ao princípio do devido processo legal substantivo - princípio este, como se sabe, explícito na Carta de 1988, com dicção no inciso LIV do art. $5^{\circ}$.

É o que se depreende, v.g., do escólio de DANIEL SARMENTO, que, após historiar alguns precedentes de julgados da Corte Suprema escorados nos princípios em tela, conclui:

"Enfim, percebe-se que, a partir sobretudo do advento da Constituição de 1988, o STF vem reconhecendo o princípio da proporcionalidade / razoabilidade no direito brasileiro. localizando sua sede na cláusula do devido processo legal, albergada no art. $5^{\circ}, \mathrm{LIV}$, do texto fundamental"..$^{20}$

Especificamente no que se refere ao Direito Tributário, também a matriz do devido processo legal substantivo é reconhecida por PAULO ROBERTO LYRIO PIMENTA $^{21}$ e por HELENILSON CUNHA PONTES ${ }^{22}$.

Como já visto acima, a evolução da cláusula do devido processo legal para uma compreensão substantiva ou material deu-se em grande medida por obra dos julgados da Suprema Corte Norte-Americana, inicialmente na garantia dos direitos econômicos e individuais, espraiando-se, depois, para o campo dos direitos fundamentais e em específico para a garantia das liberdades civis no contrapondo aos atos de autoridade perpetrados pelo Poder Público.

E nessa nova trilha também os atos de tributação passaram a ser contrastados à luz do substantive due process of law.

Em precursora obra, A.R. SAMPAIO DÓRIA se propôs a examinar o reflexo na seara do Direito Tributário das decisões da Suprema Corte Norte-Americana fundadas na cláusula do devido processo legal substantivo, tendo sido conduzido para a seguinte constatação:

"Embora vacilante de início, pela natural dificuldade em discernir dentre a multiplicidade de casos que lhe eram submetidos, os autênticos valores dignos de proteção, a Suprema Corte americana elaborou, a partir do difuso

19 Assevera o mestre gaúcho que "o princípio da proporcionalidade é autônomo em relação ao princípio do devido processo legal, sendo que a mesma autonomia deve ser atribuída ao princípio da legalidade, com a condição de que, em ambos os caos, realizem-se os indispensáveis entrelaçamentos". (A Interpretação Sistemática do Direito, Ed. Malheiros, São Paulo, 2002, p. 262.

20 Ob. cit., p. 95.

21 Ob. cit., p. 297

22 Embora reconheça que "no direito brasileiro, a razoabilidade manifesta-se na garantia do devido processo legal", o professor paulista verbera sua conviç̧ão no sentido de que a exigência da razoabilidade nas decisões judicais é haurida não apenas dessa cláusula, "mas de todos os principios e garantias constitucionais autonomamente assegurados pela ordem constitucional brasileira". (Ob. cit., p. 83.) 
conceito substantivo de due process, os seguintes postulados cardeais da tributação:

a) inexistência do direito do contribuinte à contraprestação direta pela cobrança de impostos e, contrariamente, o reconhecimento desse direito no caso das taxas e contribuiçôes de melhoria;

b) necessidade de destinação pública da receita tributária;

c) limitação da competência tributária do Estado aos atos, fatos, negócios ou pessoas vinculados a seu território:

d) igualdade perante os tributos;

e) vedação de tributos impeditivos de atividades lícitas;

f) proibição de tributos confiscatórios;

g) respeito à capacidade contributiva objetiva do sujeito passivo tributário." 23

Como à época na doutrina pátria ainda não se cogitasse dos cânones da proporcionalidade e da razoabilidade com a formatação conceitual hoje adotada, na obra em tela A.R. Sampaio Dória não chega a desenvolver as noções correlatas àqueles princípios que vieram a ser melhor depuradas nas décadas seguintes (proibição do excesso, adequação, referibilidade, racionalidade, etc.), formulando, todavia, conceitos que em essência claramente se imbricam com os postulados que os autores contemporâneos vislumbram aplicáveis no plano do Direito Tributário.

Ver-se-á, então, que também no Brasil os princípios da proporcionalidade e da razoabilidade - ainda que hauridos da cláusula do devido processo legal substantivo - encontram no Direito Tributário fértil terreno de semeadura, permitindo que nele frutifiquem as mais variadas aplicações práticas, algumas já reconhecidas pelo próprio Supremo Tribunal Federal, outras ainda objeto de cogitação por parte da doutrina.

3.2. No estreito escopo inicialmente proposto para o presente trabalho, elenca-se a seguir algumas das questões de índole tributária cuja natureza permite aplicações concretas dos princípios em foco, na trilha dos autores que já debruçaram sobre o tema. Para uma maior fidedignidade da pesquisa levada a cabo, e de modo a facilitar a compreensão das hipóteses versadas, será feita expressa menção ao(s) autore(s) que tenham se referido a cada qual das questões, com breve resumo do entendimento que esposaram, inclusive com remissão a eventuais julgados do STF pertinentes.

(i) Aplicação de Sanções Tributárias (HELENILSON CUNHA PONTES ${ }^{24}$, RICARDO AZIZ CRETTON ${ }^{25}$ ):

A aplicação dos princípios da proporcionalidade e da razoabilidade no balizamento das sanções tributárias chega a ser intuitiva. De fato, o mister de que a gradação das multas pecuniárias impingidas aos contribuintes guarde relação de proporciona-

23 Direito Constitucional Tributário e Due Process of Law, Ed. Forense, Rio de Janeiro, 1986, pp. $35 / 36$.

24 Ob. cit., pp. 129 e segs.

25 Ob. cit., pp. 133 e segs. 
lidade e de razoabilidade com a infração cometida decorre de reta aplicação dos princípios em tela. O objetivo primordial da sanção pecuniária deve se esgotar na dissuasão ao cometimento do ato ilícito, não podendo desbordar para atingir fins confiscatórios ou impeditivos do desenvolvimento em si das atividades econômicas realizadas pelo contribuinte. Da mesma forma - e pelas mesmas razões -, não se admite a interdição de estabelecimento ou a proibição de comerciar como sanções a ilícitos meramente tributários.

Vários são os julgados da Corte Suprema que incorporam tal entendimento ( $v . g$.: RE 91.707-MG, RE 82.510-SP, Súmulas STF nº 70, 323 e 547).

(ii) Valor das Taxas de Polícia ou de Serviços (PAULO ROBERTO LYRIO PIMENTA $^{26}$, RICARDO AZIZ CRETTON ${ }^{27}$ ):

Como se sabe, as taxas possuem a natureza de tributos vinculados, caracterizando-se segundo alguns autores como contraprestacionais, na medida em que sua cobrança somente se legitima a partir da efetiva realização de atos e/ou serviços do Poder Público diretamente relacionados ao contribuinte, ou ao menos postos à sua disposição. Nesse contexto - e sem adentrar a tormentosa questão do uso extrafiscal dos tributos vinculados - tem-se que o valor exigido pelo Poder Público, em contraprestação aos serviços que presta ou ao poder de polícia que exerce, deverá guardar relação de razoável equivalência com o custo incorrido. Em outras palavras, a exigência pelo ente tributante, à guisa da cobrança de taxas, de valores pecuniários desproporcionais ao efetivo custeio das atividades estatais exercidas, irá de encontro aos postulados básicos dos princípios da proporcionalidade e da razoabilidade.

Também aqui já há julgados do STF afastando a cobrança de taxas tidas como inconstitucionais por conta dos fundamentos acima resumidos (v.g.:Rep.Inc. 1.077RJ, ADIn 948-GO. ADIn 1.926-PE).

(iii) Exigência de Depósito Recursal Administrativo (RICARDO AZIZ CRET$\mathrm{TON}^{28}$, DENISE LUCENA CAVALCANTE ${ }^{29}$ ):

Desde meados da década de 1990 as Fazendas Públicas fizeram ressuscitar a exigência de depósito prévio como condição de admissibilidade de recurso administrativo, em movimento inaugurado pelo INSS, que baixou norma condicionando o conhecimento do recurso à prova de depósito em valor equivalente a $30 \%$ da glosa impugnada. A partir de então espraiaram-se pelo país exigências de igual quilate, sendo hoje encontradas não apenas na legislação do fisco federal, mas também nas regras baixadas pelos Estados-membros. Logo a ela opuseram-se os contribuintes, firmes na cláusula da garantia do devido processo legal, e nos cânones da proporcionalidade e da razoabilidade. Em resumo, alegava-se que dita exigência virtualmente impedia o livre acesso às instâncias administrativas tributárias, mormente quando o valor da glosa se afigurasse de tal monte que mesmo o depósito de $30 \%$ por si já representasse desencaixe financeiro capaz de comprometer o giro das

Ob. cit., pp. $129 / 133$.

Ob. cit., pp. 137 e segs.

29

Ob. cit., pp. $50 / 51$. 
atividades exercidas pelo contribuinte, realidade que configuraria ostensiva agressão aos princípios em foco. Até o momento o Poder Judiciário não tem sido permeável a tais alegações, mantendo o direito das Fazendas Públicas de exigir o depósito recursal administrativo - em decisões não raro consideradas superficiais, especialmente por deixarem de abordar o tema sob o enfoque da proibição do excesso.

Como visto acima, as decisões do STF atinentes ao assunto não têm acolhido o entendimento de que os cânones da proporcionalidade e da razoabilidade impediriam a exigência ora versada (v.g.: ADIn 1.992-DF, RE 210.146-SP).

(iv) Princípio da Capacidade Contributiva e Planejamento Tributário (HELENILSON CUNHA PONTES ${ }^{30}$, RICARDO AZIZ CRETTON ${ }^{31}$ ):

Sabe-se que o princípio da capacidade contributiva se encontra positivado na Carta de 1988, com expressa dicção no $\S 1^{\circ}$ do art. 145. Seu postulado fundamental se enfeixa na noção de que os tributos deverão ser graduados e exigidos respeitando a capacidade econômica dos contribuintes, razão pela qual diz-se que o limite inferior da capacidade contributiva seria "o mínimo existencial" enquanto que o seu limite superior se imbricaria com o cânone do "não-confisco" - este também positivado no art. 150, IV da Constituição vigente. Quando em cotejo com as regras anti-elisivas existentes na legislação tributária, o princípio da capacidade contributiva exige que a liberdade de planejamento tributário (direito do contribuinte ainda que exercido para fins exclusivos de economia fiscal) seja garantida com o permeio dos cânones da proporcionalidade e da razoabilidade. Sem que se estabeleça juízo preconcebido pró-fisco ou pró-contribuinte, tanto na feitura das normas anti-elisivas quanto na análise concreta das hipóteses realizadas - onde se verificará eventual abuso de forma, a tipicidade do negócio jurídico, a ocorrência de fraude, etc. - o exame do intérprete necessariamente incorporará a aplicação dos cânones ora referidos, especialmente em seus postulados da adequação, da necessidade, da racionalidade e da proporcionalidade em sentido estrito.

Embora já se encontre alguma doutrina no direito pátrio atinente ao assunto, não foram encontrados julgados oriundos das Cortes Superiores que tenham abordado, em específico, a liberdade de planejamento fiscal à luz dos princípios da proporcionalidade e da razoabilidade.

3.3. Há ainda outros nichos do Direito Tributário nos quais os cânones da proporcionalidade e da razoabilidade encontram amplo espaço para atuar, tanto no balizamento dos atos de feitura em si das normas tributárias (v.g.: na estipulação de ficções e presunções, na indexação de débitos) como na análise concreta de litígios abertos entre os contribuintes e as Fazendas Públicas. Ainda hoje, entretanto, o que se percebe é que aqueles cânones são aplicados com certa timidez nas questões tributárias, prevalecendo, especialmente nos julgados das Cortes Superiores, o enfoque formalista que induz à simples aplicação positivista das normas legisladas.

Quer-se crer, não obstante, que a paulatina mas inexorável incorporação, também às questões atinentes ao Direito Tributário, da hermenêutica pós-positivista

Ob. cit. pp. $121 / 129$. 
fundada na ponderação dos princípios e dos valores atingidos nas hipóteses concretas - para além, portanto, do uso exclusivo do positivismo formalista e dos seus cânones corolários, qual o da "tipicidade fechada" - implicará numa natural abertura, na busca das soluções dos litígios instaurados, para a aplicação dos princípios da proporcionalidade e da razoabilidade.

Tema de grande amplitude, abordado em uma de suas facetas no item (iv) acima, o que se pode prever é que cada vez mais os cânones em foco encontrarão palco de atuação no espaço hermenêutico que se descortina entre os chamados princípios de segurança jurídica (legalidade, tipicidade, não-surpresa, etc.) e os princípios de justiça fiscal (capacidade contributiva, generalidade, isonomia, etc.) - especialmente quando a solução do litígio exigir a concomitante e ponderada aplicação de princípios que se insiram em ambos os grupos acima aludidos, ensejando fricção a ser mediada pelos cânones da proporcionalidade e da razoabilidade.

É como se expressa RICARDO LOBO TORRES, em reta assertiva:

“O princípio da tipicidade tributária é um corolário do princípio da legalidade e, como tal, se subordina à idéia de segurança jurídica. Mas se abre sempre para a ponderação com o princípio da capacidade contributiva e outros vinculados à idéia de justiça". ${ }^{32}$

Conforme se viu à exaustão nos itens anteriores deste trabalho, os cânones da proporcionalidade e da razoabilidade - chame-se-os de princípios, de critérios de interpretação ou de postulados normativos de aplicação do direito, não importa assumem inegável relevância prática exatamente no ato da ponderação de outros princípios e valores de estirpe constitucional postos em confronto na solução de litígios concretos (os chamados hard cases):é na concretização daqueles cânones que o confronto será desarmado, que os princípios contrapostos serão ponderados e a solução mais justa será encontrada.

Pois no âmbito do Direito Tributário esses litígios envolverão, no limite e em regra, o confronto de princípios relativos à segurança jurídica vs. princípios relacionados à justiça fiscal. Em cada caso concreto caberá ao intérprete (seja o magistrado, a autoridade fazendária ou mesmo o jurista ou o advogado que examina a hipótese) identificar aqueles princípios postos em circunstancial oposição, para, então, buscar nos postulados da proporcionalidade e da razoabilidade a possível ponderação entre eles, trazendo como resultado dessa operação o desfecho que se afigure o mais justo para o litígio.

Esse será, portanto, ao que parece, o espaço por excelência de atuação dos princípios da proporcionalidade e da razoabilidade no âmbito do Direito Tributário: o balizamento da ponderação dos princípios relacionados à segurança jurídica com aqueles atinentes à justiça fiscal, contrapostos no bojo dos litígios instaurados entre os contribuintes e as Fazendas Públicas, mediando a inevitável friç̧ão existente para 
propiciar a harmonização desses princípios e dos valores que os informam objetivando alcançar a solução concreta mais justa para o litígio específico.

\section{Conclusões:}

De tudo o que se expôs ao longo do presente trabalho, as seguintes conclusões podem ser externadas:

- em suas modernas acepções, os princípios da proporcionalidade e da razoabilidade têm origens históricas diversas, aquele oriundo da constitucionalização implícita, no direito administrativo alemão, do princípio da proibição do excesso, e este decorrente da evolução da cláusula do devido processo legal para uma dicção substantiva ou material, operada no direito anglo-saxão, desde a Magna Carta até os julgados da Corte Suprema Norte-Americana na segunda metade do século passado:

- essas origens distintas resultam em que a proporcionalidade tenha assumido uma feição material e objetiva mais proeminente, a qual se expressa nos postulados da adequação, da necessidade e da proporcionalidade no sentido estrito quando da análise da relação meio-fim no ato jurídico posto sob exame, enquanto que a razoabilidade se expressaria em termos mais subjetivos, operando no campo hermenêutico na verificação da sintonia entre o critério e a medida adotados no ato jurídico examinado;

- em que pesem tais distinções, ambos os cânones se irmanam como poderosos instrumentos de controle dos atos de autoridade perpetrados pelo Poder Público, especialmente no âmbito da chamada hermenêutica pós-positivista, que se funda na ponderação dos princípios e valores constitucionais como procedimento complexo visando a solucionar os casos concretos exsurgentes de litígios que contraponham aqueles princípios e valores;

- no direito brasileiro as aplicações mais recentes dos princípios da proporcionalidade e da razoabilidade pela Suprema Corte se vinculam à cláusula do devido processo legal, positivada no art. $5^{\circ}$, LIV da CF/88, não obstante a doutrina reclame uma atuação autônoma dos cânones em foco, com matriz alocada diretamente sobre os direitos fundamentais que a Constituição sanciona, e cuja proteção exsurge como apanágio primeiro daqueles princípios;

- especificamente no âmbito do Direito Tributário os princípios da proporcionalidade e da razoabilidade encontram vários nichos de aplicação concreta, tanto na feitura em si das normas tributárias quanto na solução dos litígios instaurados entre os contribuintes e as Fazenda Públicas. É entretanto na solução desses litígios que os cânones em tela assumem especial relevância e importância prática, pois servirão como instrumentos na mediação do confronto entre os princípios da segurança jurídica (legalidade, tipicidade, não-surpresa, etc.) e os principios da justiça fiscal (capacidade contributiva, generalidade, isonomia, etc.) eventualmente contrapostos, propiciando sejam ponderados na busca da obtenção do mais justo desenlace para o litígio concreto. 
ÁVILA, Humberto. Teoria dos Princípios - da definição à aplicação dos princípios jurídicos, Ed. Malheiros, São Paulo, 2003.

BARCELLOS, Ana Paula de; BARROSO, Luis Roberto. O Começo da História. A Nova Interpretação Constitucional e o Papel dos Princípios no Direito Brasileiro, in: A Nova Interpretação Constitucional - Ponderação, Direitos Fundamentais e Relações Privadas (org. Luís Roberto Barroso), Ed. Renovar, Rio de Janeiro, 2003.

BARROSO, Luis Roberto. Fundamentos Teóricos e Filosóficos do Novo Direito Constitucional Brasileiro, in: A Nova Interpretação Constitucional - Ponderação, Direitos Fundamentais e Relações Privadas (org. Luís Roberto Barroso), Ed. Renovar, Rio de Janeiro, 2003.

CAVALCANTE, Denise Lucena. A Razoabilidade e a Proporcionalidade na Interpretação Judicial das Normas Tributárias, in: Temas de Interpretação do Direito Tributário (org. Ricardo Lobo Torres), Ed. Renovar, Rio de Janeiro, 2003.

CRETTON, Ricardo Aziz. Os Princípios da Proporcionalidade e da Razoabilidade e sua Aplicação no Direito Tributário, Ed. Lumen Juris, Rio de Janeiro, 2001.

DÓRIA, A.R. Direito Constitucional Tributário e Due Process of Law, Ed. Forense, Rio de Janeiro, 1986.

FREITAS, Juarez. A Intepretação Sistemática do Direito, Ed. Malheiros, São Paulo, 2002.

GRAU, Eros Roberto. Ensaio e Discurso sobre a Intepretação / Aplicação do Direito, Ed. Malheiros, São Paulo, 2002.

PIMENTA, Paulo Roberto Lyrio. A Razoabilidade das Leis Tributárias, in: Tributos e Direitos Fundamentais (org. Octavio Campos Fischer), Ed. Dialética, São Paulo, 2004.

PONTES, Helenilson Cunha. O Princípio da Proporcionalidade e o Direito Tributário, Ed. Dialética, São Paulo, 2000.

SARMENTO, Daniel. A Ponderação de Interesses na Constituição Federal, Ed. Lumen Juris, Rio de Janeiro, 2002.

TORRES, Ricardo Lobo. O Princípio da Tipicidade no Direito Tributário, RDA 235/193 e segs., 2004. 


\section{A Constituição Européia - O Projeto de uma nova Teoria Constitucional}

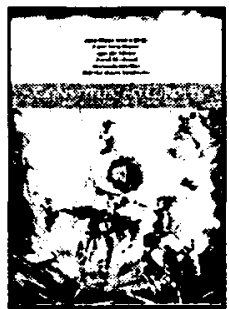

Jose Ribas Vieira (org.)

Ret. 0501

Brochura

272 págs.

Form. $14 \times 21$

2004

ISBN 85-7147-431-1

É leitura indispensável para o estudo da atual fase do Direito Constitucional, pois confere ao teitor subsídios importantes sobre a questão dos Direitos Fundamentais que servem para avaliar se há ou não um possivel esgotamento da Teoria Constitucional pós-1945. Para tratar, também, do problema do déficit de legitimidade da Constituição Européia, esta obra é ainda útil para as disciplinas do Direito vinculadas à Teoria do Estado e à própria Ciência Política.

\section{A Eficácia Jurídica dos Princípios Constitucionais}

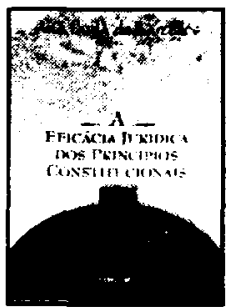

\author{
Ana Paula de Barcellos \\ Ref. 0373 \\ Brochura \\ 342 págs. \\ Form. $13,5 \times 21$ \\ 2002 \\ ISBN $85-7147-471-0$
}

Procura demonstrar que 0 direito, especialmente o direito constitucional, tem um papel a desempenhar na soluçāo do problema da distribuição de bens sociais. Intenta-se responder à pergunta: qual a eficácia jurídica dos principios e das regras constitucionais que tratam da dignidade da pessoa humana, especialmente daqueles que impõem ao Estado o fornecimento de determinados bens ou serviços.

\section{A Liberdade de Imprensa e o Direito à} Imagem

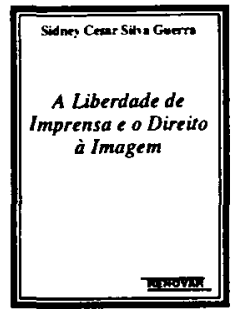

Sidney Cesar Silva Guerra

Ref. 0234

Brochura

214 págs.

Form. $14 \times 21$

$2004 / 2^{2}$ ed.

ISBN 85-7147-373-0

A imprensa livre é fundamental para garantir outras liberdades e para consolidação da democracia. Os problemas surgem quando a imprensa utiliza seu grande poder de forma incorreta, podendo provocar danos imensuráveis para uma pessoa e até para toda uma família. 0 exercício abusivo da liberdade de expressão não pode olvidar 0 princípio fundamental do Estado Democrático de Direito: a dignidade da pessoa humana.

\section{A Nova Interpretação Constitucional Ponderação, Direitos Fundamentais e Relações Privadas}

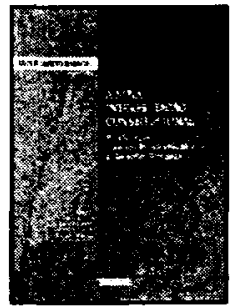

Luis Roberto Barroso

Ref. 0478

Encadernado

419 págs.

Form. $16 \times 23$

2003

ISBN: $85-7147-409-5$

A obra reúne trabalhos dotados de densidade teórica, criatividade, voltados para o país e 0 avanço do processo social. Todos eles têm como traço comum o texto denso, comprometido com a clareza e com a socialização das idéias. A linguagem não deve ser um instrumento de poder e de exclusão, mas uma forma de ampliação do acesso ao debate e de participação esclarecida no processo deliberativo. 